\title{
Effects of Monosodium Glutamate Oral Administration on LH and Testosterone Levels in Serum of Adult Male Rats (Rattus norvegicus)
}

\author{
Riska Annisa1, Moch. Sasmito Djati² ${ }^{2}$ Sri Rahayu ${ }^{2 *}$ \\ ${ }^{1}$ Master Program of Biology, Faculty of Mathematics and Natural Sciences, University of Brawijaya, Malang, Indonesia \\ ${ }^{2}$ Department of Biology, Faculty of Mathematics and Natural Sciences, University of Brawijaya, Malang, Indonesia
}

\begin{abstract}
This study aims to determine the effect of monosodium glutamate on $\mathrm{LH}$ and testosterone levels in serum of adult male rats (Rattus norvegicus). A total of 12 male Wistar-strained rats divided into three groups with 4 rats per group. Control group was given distilled water, while M1 was given MSG at a dose of $4 \mathrm{mg} . \mathrm{gBW}^{-1}$ for 15 days and M2 was given MSG at a dose of $4 \mathrm{mg} . \mathrm{gBW}^{-1}$ for 45 days. All substances were given orally. At the end of the study, rats were sacrificed with a dislocation to draw blood from the heart. Then, the blood was incubated at room temperature to obtain serum. Serum was used to analyze LH and testosterone levels using the ELISA kit. Data were analyzed using one way ANOVA $(p \leq 0.05)$ with SPPS 16.0 for windows. The results showed that serum LH levels after MSG treatment for 45 days was significantly decreased compare with the control. The serum testosterone levels M2 was significantly different from the control group $(p \leq 0.01$ ). This study predicts that monosodium glutamate have a direct and indirect effect on male reproductive organs.
\end{abstract}

Keywords: Luteinizing hormone, monosodium glutamate, testosterone.

\section{INTRODUCTION}

In the past few decades, monosodium glutamate (MSG) has become the most famous flavoring used throughout the world [1,2]. MSG can be easily found in packaged foods, fast food, and household kitchens. MSG has been categorized as a flavor enhancer that is safe for consumption. However, its use is increasing globally including in Asia with 4 g.day ${ }^{-1}$ and in Europe around 1 g.day ${ }^{-1}$ [3]. Progress in the practice of food production and the need for food preservation cause the advised amount of MSG consumption is exceeded in a short time. Consumption of MSG allowed by the FDA (Food and Drug Administration) and the WHO (World Health Organization) is $120 \mathrm{mg} . \mathrm{kg}^{-1}$ day [4].

Excessive consumption of MSG has a detrimental effect on humans and experimental animals $[1,5]$. MSG can cause damage to the male reproductive system by increasing Reactive Oxygen Species (ROS) in the brain [6] and testicles [7]. Excessive MSG exposure can increase L-glutamate level in the blood which then spreads throughout the body, especially in the brain and testicles. The high levels of L-glutamate cause overstimulation of the glutamate receptor resulting in increase intracellular $\mathrm{Ca}^{2+}$ ions [8]. This causes excessive entry of calcium ions into the mitochondria and

*Correspondence address:

Sri Rahayu

Email : yayuksrirahayu8@gmail.com

Address : Dept. Biology, University of Brawijaya, Veteran Malang, Malang 65145. consequently increases the production of ROS [9]. The excitotoxicity effect of MSG causes interference with the hypothalamic-pituitary-axis (HPA) pathway [10]. Disruption in the HPA pathway decreases the production of gonadotropin-releasing hormone $(\mathrm{GnRH})$. It decreases luteinizing hormone (LH) released from the anterior pituitary. Reduced stimulation of $\mathrm{LH}$ in Leydig cells decreases testosterone production which ultimately leads to decreased sperm concentration $[1,11]$. Increased ROS in the testes caused lipid peroxidation resulting in disruption of membrane permeability and ATP synthesis which results in death in Leydig cells $[12,13]$. Decreasing the number of Leydig cells decreases the production of testosterone in the testis [14].

Sarhan [15] reported, MSG at a dose of 6 mg.gBW ${ }^{-1}$ per day for 45 days in male rats increased the production of reactive oxygen species (ROS) which was marked by an increase in MDA levels significantly. In addition, there is damage in the testis in the form of a decrease in the diameter and height of the epithelial layer in the seminiferous tubules. Spermatogenic cells, Sertoli cells, and Leydig cells show irregular nuclei, cytoplasmic vacuolation, and swelling of the mitochondria. Farombi and Onyema [6] mentioned intraperitoneal administration of a dose of $4 \mathrm{mg} \mathrm{g}^{-1} \mathrm{BW}$ in male rats caused an increase in ROS in the brain. This results in damage to the male reproductive system [16].

Therefore, this study aims to explain the effect of MSG on LH and testosterone levels 
serum in male rats (Rattus norvegicus). Male rats were given oral MSG at a dose of $4 \mathrm{mg} \mathrm{gBW}^{-1}$ (a third of LD50) for 15 days and 45 days.

\section{MATERIALS AND METHODS Research Materials}

Total of 12 sexually mature male rats (Rattus norvegicus) with a weight of 200-300 g aged 3-4 months were used in this study. The experimental animals were kept in standard clean rat cages $(32 \times 28 \mathrm{~cm})$ with rodent pellets and water available ad libitum. The animals were acclimatized for 2 weeks before and during the study at Animal House, the Laboratory of Structure Physiology and Animal Development, Department of Biology, Faculty of Mathematics and Natural Sciences, Brawijaya University, Malang.

\section{Monosodium glutamate}

In this study, the daily dose of MSG was $4 \mathrm{mg}$ $\mathrm{g}^{-1} \mathrm{BW}$ given orally to male rats. MSG was obtained from the local market in Malang.

\section{Experimental design}

Total of 12 rats chosen randomly were divided into 3 groups $(n=4)$. The groups consisted of a control group (M0), MSG treatment group $\mathrm{M} 1$ and $\mathrm{M} 2$.

M0 (control group) : distilled water for 45 days

M1 (treatment MSG 1): 4 mg.gBW ${ }^{-1}$ for 15 days

M2 (treatment MSG 2): 4 mg.gBW ${ }^{-1}$ for 45 days

After given MSG, all experimental animals were dislocated and blood was drawn from the heart. The obtained blood was incubated at room temperature for 6 hours. After that, the serum obtained was stored at $-20^{\circ} \mathrm{C}$.

\section{Testosterone Serum and LH Assay}

Testosterone and LH concentrations in serum were analyzed using Rat Testosterone ELISA kit 96T (E0259Ra) and Rat LH ELISA kit 96T (E0179Ra) the Bioassay Technology-Laboratory.

\section{Statistical Analysis}

Data were analyzed using one-way ANOVA $(p<0.05)$ with SPSS 16.0 for windows.

\section{RESULTS AND DISCUSSION \\ Effects of MSG on serum levels of LH}

Figure 1(a) presents the decrease of LH levels along with the length of MSG exposure. However, in the statistical test, the MSG treatment group for 15 days (M1) did not show a significant difference with the control group. While the MSG treatment group for 45 days (M2) show a significant difference with the control.

In this study, the LH level of M2 was significantly different from the control (M0). This study conducted by Ochiogu et al. [1] which stated that MSG can significantly reduce LH level. MSG is reported to have an indirect effect on male reproductive organs through interference with the pathway of the HPA [17]. MSG can cause an increase in L-glutamate level in the hypothalamus resulting in intracellular calcium $\left(\mathrm{Ca}^{2+}\right)$ influx [18].
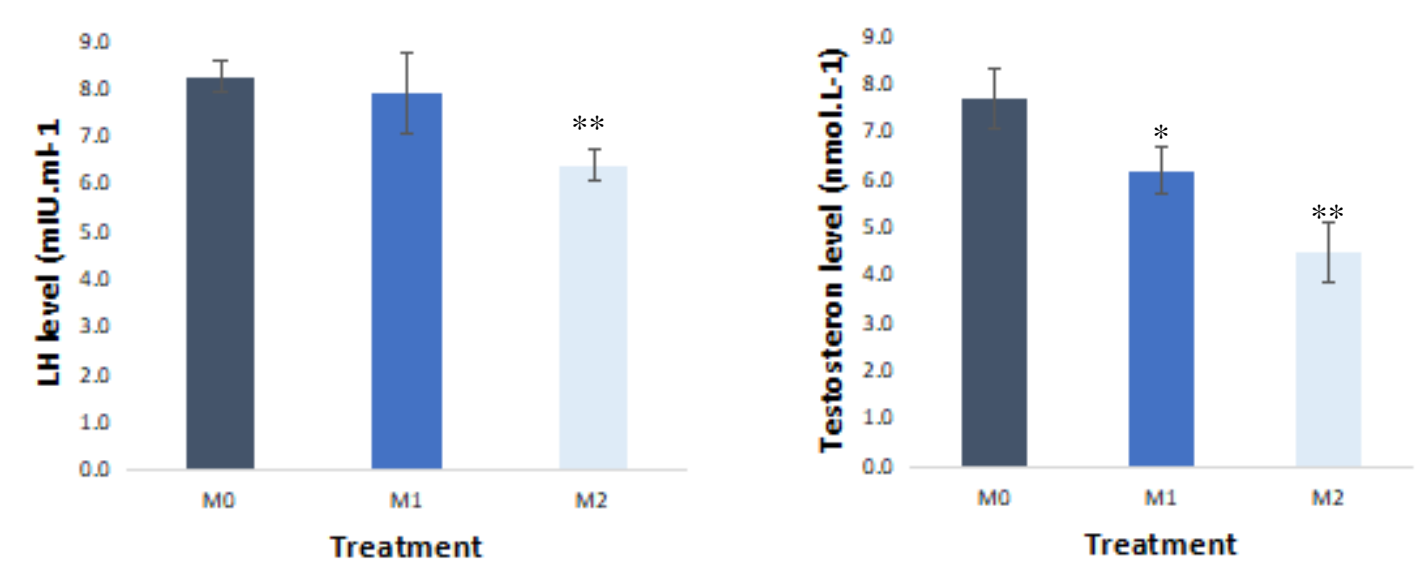

Figure 1. LH and Testosterone Level in Rats Serum

Description: (a) LH serum levels (mlU. $\mathrm{ml}^{-1}$ ) determined after treatment in control (MO) and MSG-treated groups (M1: MSG for 15 days and M2: MSG for 45 days), (b) Testosterone serum levels (nmol. $\mathrm{L}^{-1}$ ) determined after treatment in control and MSG-treated groups. Statistically significant difference from control showed by ${ }^{*} p<0.05 ;{ }^{* *} p<0.01$. 
L-Glutamate can activate NMDA receptors in the hypothalamus causing large quantities of calcium ions $\left(\mathrm{Ca}^{2+}\right)$ along with sodium ions through the AMPA receptor. The excessive concentrations of calcium ions $\left(\mathrm{Ca}^{2+}\right)$ in the intracell results in mitochondrial dysfunction followed by the release of free radicals and the stimulation of the MAPK protein p38 (mitogen-activated protein kinase p38) which activates transcription factors. This results in damage and neuronal cell apoptosis $[19,20]$. Park et al. [21] reported, MSG at a dose of $4 \mathrm{mg} \mathrm{g}^{-1}$ $\mathrm{BW}$ in adult rats gave rise to neurodegeneration in the form of fewer neurons than controls. It was also found damage to the nucleus arkuata in the hypothalamus which played a role in $\mathrm{GnRH}$ regulation. The decrease in $\mathrm{GnRH}$ influences the release of $\mathrm{LH}$ from the anterior pituitary [1]. LH interacts with receptors on Leydig cell membranes to synthesize and secrete testosterone.

\section{Effects of MSG on serum levels of testosterone}

The average testosterone concentration of group M1 (MSG $4 \mathrm{mg} . \mathrm{gBW}^{-1}$ for 15 days) was significantly lower compared to the control group. M2 Group (MSG 4 mg.gBW ${ }^{-1}$ for 45 days) had a very significant difference with the control group ( $p \leq 0.01$ ) (Fig. 1b).

Decreased testosterone can occur due to decreased LH level [1]. In this study, the decrease in LH did show a significant difference after MSG treatment for 45 days. In addition, a decrease in serum testosterone was probably caused by damage and a decrease in the number of Leydig cells in the testis. Leydig cells are cells that play a role in producing the testosterone hormone located between seminiferous tubules (interstitial space) [22]. According to a study by Suryadi [23], the Wistar strain of male rats (Rattus norvegicus) given a dose of $4800 \mathrm{mg} \mathrm{kg}^{-1}$ BW/day MSG for 49 days showed that the Leydig cell's core diameter was smaller than those in control group. In addition, the number of Leydig cells decreased significantly compared to those in the control group. This decrease in the number of Leydig cells was caused by an increase in the production of ROS in testis [7].

Increased ROS is caused by a high level of L-glutamate due to excessive consumption of MSG for a long time [24,25]. L-glutamate in high concentrations in the testis can activate excess glutamate receptors. The activation of the glutamate receptor can lead to the increasing of $\mathrm{Ca}^{2+}$ intracell. Natrium enters and triggers cell depolarization which causes activation of NMDA receptors. Therefore, $\mathrm{Ca}^{2+}$ can enter intracell [26]. $\mathrm{Ca}^{2+}$ ions which enter into mitochondria in excessive amounts cause deviations in mitochondrial electron chain function leading to excessive production of ROS [27]. ROS is released in the form of $\mathrm{O}_{2}$ and then converted to $\mathrm{H}_{2} \mathrm{O}_{2}$. Then, hydrogen peroxide $\left(\mathrm{H}_{2} \mathrm{O}_{2}\right)$ reacts with $\mathrm{Fe}^{2+}$ through a Fenton reaction that forms $\mathrm{OH}^{-}$and lipid peroxidation. Lipid peroxidation causes damage to cell membranes, especially the content of phospholipids, DNA damage, and protein molecules [9]. This can lead to ruptured cell membranes and necrosis, causing a decrease in the number of Leydig cells [12]. The decrease in the number of Leydig cells effects the testosterone production and testosterone levels in the testes [14]. In the study of Igwebuike et al. [28], oral administration of monosodium glutamate at a dose of $4 \mathrm{mg} \mathrm{g}^{-1} \mathrm{BW}$ in Sprague-Dawley rats every 48 hours for 6 weeks can reduce sperm reserve in cauda epididymis $(P<0.05)$ and serum testosterone levels significantly.

\section{CONCLUSION}

Based on the results of this study, it can be concluded that the administration of MSG in male rats (Rattus norvegicus) can cause a significant decrease in $\mathrm{LH}$ and testosterone. This study predicts that monosodium glutamate have a direct and indirect effect on male reproductive organs.

\section{Acknowledgement}

The authors thank the Ministry of Research, Technology and Higher Education, the Republic of Indonesia for the financial support according to the research contract number: 055/SP2H/LT/DRPM/2019, March $11^{\text {th }} 2019$.

\section{REFERENCES}

[1] Ochiogu, I.S., O. David, N.U. Chukwuka, N.O., Chidozie, I.I. John, C.M. Edmund. 2015. Effect of monosodium L-glutamate administration on serum levels of reproductive hormones and cholesterol, epididymal sperm reserve and testicular histomorphology of male albino rats. Acta Veterinaria Hungarica. 63(1). 125-139.

[2] Onaolapo, O.J., A.Y., Onaolapo, M.A. Akanmu, O. Gibola. 2016. Evidence of alteration in brain structure and antioxidant status following 'low dose' monosodium glutamate ingestion. Pathophysiology. 23(3). 147-156. 
[3] Park, E., K.H. Yu, D.K. Kim, S. Kim, K. Sapkota, S.J. Kim, C.S. Kim, H.S. Chun. 2014. Protective effects of $\mathrm{N}$-acetylcysteine against monosodium glutamate-induced astrocytic cell death. Food and Chemical Toxicology. 67. 1-9.

[4] Oleksandra, A.S., V.V. Oleksandra, T.M. Falalyeyeva, L.P. Babenko, L.M. Lazarenko, O.M. Demchenko, R.V. Bubnov, Y.S. Mykola. 2014. The efficacy of probiotics for monosodium glutamate-induced obesity: Dietology concerns and opportunities for prevention. EPMA J. 5(1). 2.

[5] Shimada, A., B.E. Cairns, N. Vad, K. Ulriksen, A.M.L. Pedersen, P. Svensson, L. Baad-Hansen. 2013. Headache and mechanical sensitization of human pericranial muscles after repeated intake of monosodium glutamate (MSG). The Journal of Headache and Pain. 14(2). 1-9.

[6] Farombi, E., O. Onyema. 2006. Monosodium glutamate-induced oxidative damage and genotoxicity in the rat: Modulatory role of vitamin C, vitamin E, and Quercetin. Human and Experimental Toxicology. 25(5). 251-259.

[7] Vinodini, N., A. Nayanatara, K. Gowda, B. Ahamed, C. Ramaswamy, R. Bhat. 2008. Effect of monosodium glutamate-induced oxidative damage on rat testis. Journal of Clinical Medicine. 3. 370-373.

[8] Kazmi, Z., F., Iffat, P. Shaghufta, S.M. Saima. 2017. Monosodium glutamate: Review on clinical reports. International Journal of Food Properties. 20(S2). S1807-S1815.

[9] Szydlowska, K., M. Tymianski. 2010. Review: calcium, ischemia, and excitotoxicity. Cell Calcium. 47(2). 122-129.

[10] Cattani, D., V.L. Cavalli, C.E.H. Rieg, J.T. Domingues, T. Dal-Cim, C.I. Tasca, F.R. Silva, A. Zamoner. 2014. Mechanisms underlying the neurotoxicity induced by glyphosate-based herbicide in immature rat hippocampus: involvement of glutamate excitotoxicity. Toxicology. 320. 34-45.

[11] lamsaard, S.W. Sukhorum, R. Samrid, J, Yimdee, P. Kanla, K. Chaisiwamongkol, W. Hipkaeo, D. Fongmoon, H. Kondo. 2014. The sensitivity of male rat reproductive organs to monosodium glutamate. Acta Medica Academica. 43(1). 3-9.

[12] Turner, T.T., J.J. Lysiak, 2008. Review oxidative stress: A common factor in testicular dysfunction. Journal of Andrology. 29(5). 448-498.
[13] Kumar, V., A.K. Abbas, N. Fausto, R.N. Mitchell, 2010. Robbins basic pathology, $8^{\text {th }}$ Ed. WB Saunders Company. Philadelphia.

[14] Sedha, S., S. Kumar, S. Shukla. 2015. Role of oxidative stress in male reproductive dysfunctions with reference to phthalate compounds. Urology Journal. 12(5). 2304-2316.

[15] Sarhan, N.R. 2018. The ameliorating effect of sodium selenite on the histological changes and expression of caspase- 3 in the testis of monosodium glutamate-treated rats: light and electron microscopic study. Journal of Microscopy and Ultrastructure. 6(2). 105-115.

[16] Molina, P.E. 2010. Chapter 8: Male reproductive system. Endocrine Physiology. NY: McGraw-Hill. New York.

[17] Seo, H.J., H. Hyang-Do, H.L. Hyung, x H.L., Woo, S.B. Hyun, P. Soo-Ah, S.K. Yong, C.C. Suck, L. Seoul, , J.O. Kyung, S.K. Byung, R.P. Byung, Y.L. Moon. 2010. Chronic administration of monosodium glutamate under chronic variable stress impaired hypothalamic-pituitary-adrenal axis function in rats. Korean J Physiol Pharmacol. 14(4). 213-221.

[18] Abdallah, C.G., L. Jiang, H.M. De Feyter, M. Fasula, J.H. Krystal, D.L. Rothman, 2014. Glutamate metabolism in major depressive disorder. The American Journal of Psychiatry. 171(12). 1320-1327.

[19] Dobrek, L., P. Thor. 2011. Glutamate NMDA receptors in pathophysiology and pharmacotherapy of selected nervous system diseases. Postepy Hig. Med. Dosw. 65. 338-46.

[20] Sengul, G. Suleyman, C. Cakir, M. Coban, M. K. Saruhan, F. and A. Hacimuftuoglu. 2011. Neuroprotective effect of ACE inhibitors in glutamate-induced neurotoxicity: rat neuron culture study. Turkish Neurosurgery. 21(3). 367-371.

[21] Park, C.H., S.H. Choi, Y. Piao, S.H. Kim, Y.J. Lee, H.S. Kim. 2000. Glutamate and aspartate impair memory retention and damage hypothalamic neurons in adult mice. Toxicology Letters. 115(2). 117-125

[22] Inoue, M., T. Baba, K. Morohashi. 2018. Recent progress in understanding the mechanisms of Leydig cell differentiation. Molecular and Cellural Endocrinology. 468. 39-46.

[23] Suryadi, E., I. Detty, K.E. Sri. 2007. Changes in adult male Leydig cells (Rattus 
norvegicus) after oral monosodium glutamate administration. Jurnal Anatomi Indonesia. 1(3). 129-132.

[24] Jinap, S., P. Hajeb. 2010. Research review glutamate: It's application in food and contribution to health. Appetite. 55(1). 1-10.

[25] Kurihara, K. 2015. Umami the fifth basic taste: history of studies on receptor mechanisms and role as a food flavor. BioMed Research International. 2015(6).1-10.

[26] Rang, H.P., M.M. Dale, J.M. Ritter, P.K. Moore, 2011. Pharmacology range dale's, $7^{\text {th }}$ Ed. Elsevier. Churchill Livingstone.

[27] Görlach, A., K. Bertram, S. Hudecova, O. Krizanova. 2015. Calcium and ROS: A mutual interplay. Redox Biology. 6. 260-271.

[28] Igwebuike, U.M., I.S. Ochiogu, B.C. Ihedinihu, J.E. Ikokideand, I.K. Idika. 2011. The effects of oral administration of Monosodium Glutamate (MSG) on the testicular morphology and cauda epididymal sperm reserves of young and adult male rats. Veterinarski Arhiv. 81(4). 525-534 